\title{
術前に予測して鏡視下に摘出しえた、 ダグラス窩に見られた卵巣外成熟囊胞性奇形腫の一例
}

公立豊岡病院組合立豊岡病院産婦人科 ${ }^{1)}$ 、大津市民病院産婦人科 ${ }^{2)}$ 小椋淳平 ${ }^{1)}$ 、山ノ井康二 ${ }^{1)}$ 、平山貴裕 ${ }^{2}$ 、安本晃司 ${ }^{1)}$ 、杉並 興 $^{1)}$

\section{A case of preoperatively-predicted extragonadal mature cystic teratoma in the pouch of Douglas resected via laparoscopic surgery.}

\author{
Jumpei Ogura ${ }^{1)}$, Koji Yamanoi $^{1)}$, Takahiro Hirayama ${ }^{2)}$, Koji Yasumoto ${ }^{1)}$, Koh Suginami ${ }^{1)}$ \\ Department of Obstetrics and Gynecology, Toyooka Public Hospital ${ }^{1)}$, \\ Department of Obstetrics and Gynecology, Otsu City Hospital ${ }^{2)}$
}

\begin{abstract}
Mature cystic teratomas derived from extragonadal lesions are rare. We report a case of extragonadal mature cystic teratoma (EMCT) in the pouch of Douglas (POD), which was predicted preoperatively and successfully resected by performing laparoscoic surgery. A 35-year-old woman was incidentally diagnosed with a mass measuring $6 \mathrm{~cm}$ in diameter in the right pelvis on ultrasonographic examination. Magnetic resonance imaging (MRI) findings were suggestive of mature cystic teratoma. Both normal ovaries were found adjacent to the mass. We considered the possibility of EMCT, and performed laparoscopic surgery.

Intraoperatively, the cyst was found in the POD and both ovaries appeared normal. There were violin string-like adhesions between the cyst wall and the back of the uterus, right ovary, and serosa of the rectum. We dissected the adhesions with the rectum with the help of a gastroenterological surgeon, and dissected the other adhesions easily ourselves. The patient had an uneventful postoperative course and was discharged on the fourth post-operative day. Pathological examination of the resected mass revealed the mass to be EMCT.

Only approximately 20 cases of EMCTs in POD have been reported till date. There are several hypotheses to explain their etiopathogenesis. We hypothesize that auto-amputation could be the mechanism that resulted in EMCT in this case. Though EMCTs are rare, we should consider performing detailed preoperative evaluations with EMCT as a differential diagnosis. Subsequently, we can plan an appropriate surgical approach beforehand, and perform laparoscopic surgery safely.
\end{abstract}

Key words: Extragonadal mature cystic teratoma, pouch of Douglas, laparoscopic surgery

\section{緒言}

胚細胞性腫瘍の一つである成熟囊胞性奇形腫 は、卵巣に好発することが知られており、卵巣腫 瘍の約 20-25\%を占める。稀に卵巣外に発生す る成熟囊胞性奇形腫の例もあるが、多くは卵巣に 発生し、卵巣以外に発生する成熟囊胞性奇形腫は $0.4 \%$ 程度を占めるのみで極めて珍しい1）その ため、特に骨盤内に腫瘍が存在する場合、術前は 頻度が圧倒的に多い卵巣原発と誤認し、術中に卵
巣外成熟襄胞性奇形腫と判明する事が度々報告さ れている2-11)。今回我々はダグラス窩に認められ た成熟囊胞性奇形腫について、術前の詳細な検討 から卵巣外発生の成熟囊胞性奇形腫を疑い、他科 と事前に連携して安全に鏡視下にて腫瘍を摘出で きた症例を経験したため、報告する。

\section{症例}

症例は35歳、3 妊 3 産。

初経12歳で、月経周期は27日で整、6 日間持続、 
月経困難症は見られなかった。

既往歴、家族歴に特記事項は無かった。

現病歴：経腟分娩後、1 个月健診にて施行した経 胵超音波検査にて、子宮背側右側に、 $5.7 \mathrm{~cm} \times$ $6.5 \mathrm{~cm} \times 6.2 \mathrm{~cm}$ 大の腫瘤を偶発的に認めた。超音 波所見にて、腫瘤は単房性で充実性壁在結節は明 らかでなく、内部にhair ball様の所見を認めた。 また正常左卵巣は描出できたものの右卵巣は描出 されたなったため、腫瘍は右卵巣由来のものであ ろうと、この時点では推測した。その後、MRI検 査を施行した。その画像において、腫藘は境界明 瞭で辺縁整、T1強調画像、T2強調画像で共に高 信号を呈しており（Figure 1A，B）、脂肪抑制画 像にて抑制されていた (Figure 1C)。充実成分 や壁在結節はみとめられなかった（Figure 1)。 また左右卵巣を詳細に検討したところ、腫瘍とは 別に、正常構造の左右卵巣を確認する事ができた (Figure 1A)。腫瘍マーカーはCA125 :15.5 U/ml, CA19-9 : $8.1 \mathrm{U} / \mathrm{ml}, \mathrm{SCC}: 1.1 \mathrm{ng} / \mathrm{ml}$ と上昇は認め なかった。

以上より、腫瘍は成熟囊胞性奇形腫で、左右卵

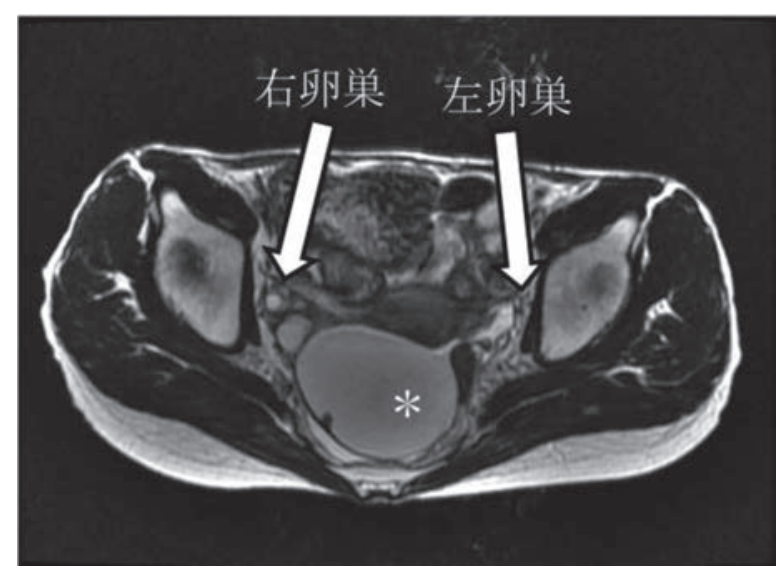

A

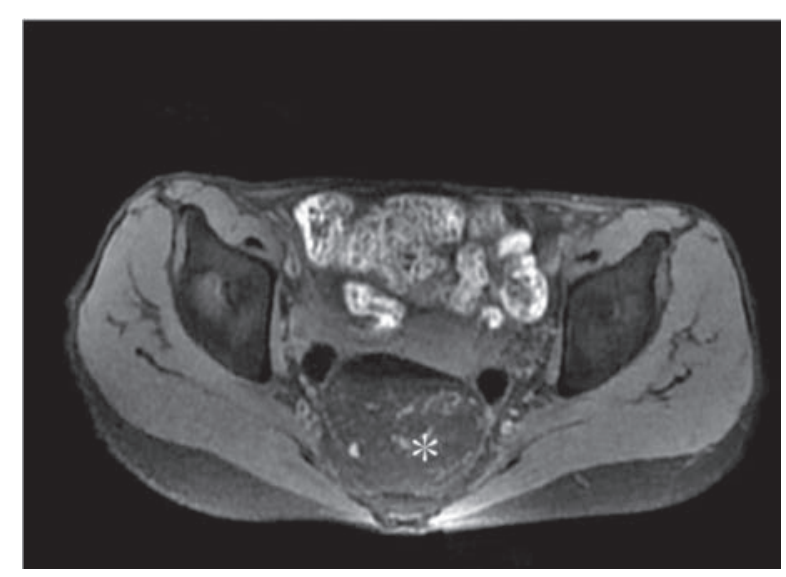

C
巣が確認できた事から、稀であるが卵巣外成熟囊 胞性奇形腫を術前に最も疑った。腫瘍は $6 \mathrm{~cm}$ を 超すものであり、無症状ではあるが手術適応にあ ると判断した。卵巣外が発生母地である場合、周 囲腸管との癒着が考えられたため、消化管外科に 連携を依頼した上で、腹腔鏡下腫瘍切除術を施行 することとした。

全身麻酔、砕石位、気腹法にて手術を行った。 臍にオープン法にて $12 \mathrm{~mm}$ トロッカーを挿入、 右下腹部に鏡視下に $11 \mathrm{~mm}$ トロッカーを挿入、 下腹部正中と左下腹部に $5 \mathrm{~mm}$ トロッカーを挿入 した。また子宮内にマニピュレーターを挿入して、 子宮の毫引を行った。

腹腔内を観察したところ、右卵巣、卵管とも概 ね正常で、左卵巣は萎縮しているように見えた。 腫瘍は骨盤腹腔内にあり、子宮右背側に位置して いた。右仙骨子宮勒帯と最も強く癒着していたが、 鏡視下に十分観察したものの栄養血管は明らかで なかった。その他右卵巣・子宮背側との間に疎な 癒着があり、直腸漿膜との間には膜状に癒着が見 られた。そして左卵管采と細い索状物でつながっ

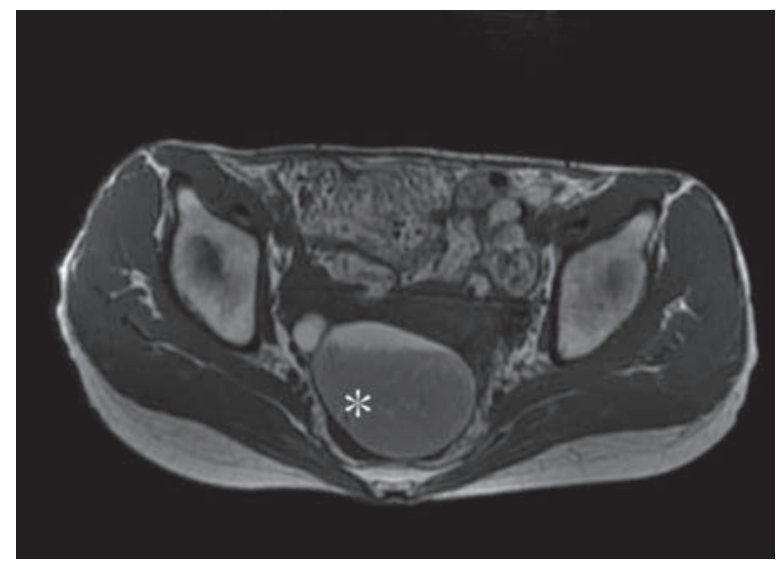

B

Figure 1 : 術前MRI水平断画像。*骨盤内腫瘍 A: T2強調画像。左右卵巣構造が確認できる。

$\mathrm{B}: \mathrm{T} 1$ 強調画像。腫瘍腹側はT1高信号を呈する。

$\mathrm{C}: \mathrm{T} 1$ 強調脂肪抑制画像。腫瘍内のT1高信号域に、脂肪抑制 効果が顕著である。 
ていた (Figure 2A)。

子宮、卵巣と腫瘍の瘉着は軽度で容易に剥離で きた。しかし直腸漿膜と腫瘍の癒着が強固であっ たため、直腸漿膜原発の成熟囊胞性奇形腫の可能 性も考えられた。当院消化管外科医師の指導の下 に腫瘍と直腸漿膜の癒着剥離を行った。鏡視下に 視野を拡大して慎重に検討したところ、腫瘍は直 腸漿膜の切開が必要ない位置で癒着していること が分かった。モノポーラーやシーリングデバイス を用いて慎重に腫瘍と直腸漿膜を全周性に剥離し た (Figure 2B)。その後腫瘍内容液を吸引し (160 $\mathrm{ml}$ 、乳白色泥状)、最も強く癒着していた右仙骨 子宮勒带と腫瘍との間を尿管に留意して慎重に剥 離し、腫瘍を摘出した（Figure 2C)。

標本を回収袋に入れて臍トロッカー部位より摘 出をした。腹腔内を十分に洗浄して奇形腫成分の 遺残が無い事と、出血が無い事とを確認して、手 術を終了した。手術時間は 2 時間17分、出血量は 少量であった。術後経過は良好で、術後4日目に 退院となった。

腫瘍内腔は平滑で $5 \mathrm{~mm}$ 大の突起が認められ (Figure 3A)、内容物には毛髪を認めた（Figure 3B)。病理学的検查にて、囊胞内腔壁は異型のな い角化型重層扁平上皮で構成されており、その他 皮脂腺や毛根も認められた（Figure 3C)。以上 より、成熟囊胞性奇形種と診断した。一方、卵巣

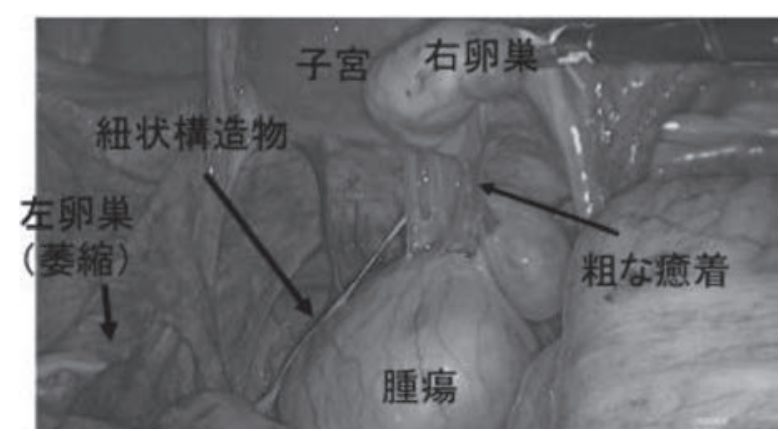

A

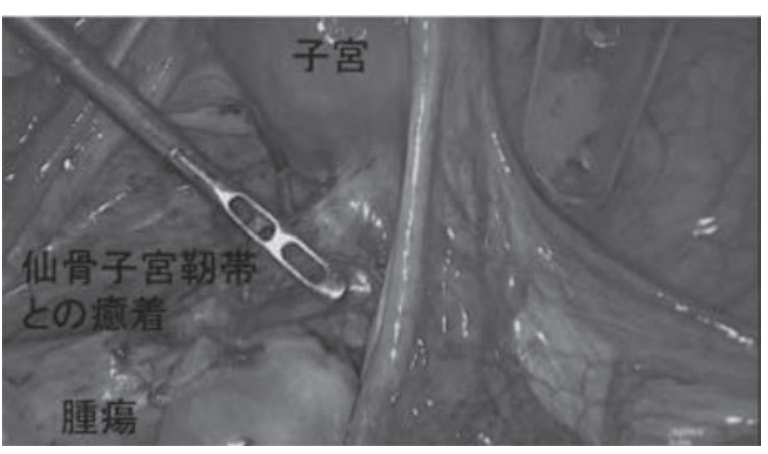

C
間質成分は全く認められず、卵巣外成熟囊胞性奇 形腫と考えられた。

以後外来にて経過観察としているが、術後 1 年 の状態で、再発を認めていない。

\section{考察}

卵巣成熟囊胞性奇形腫は全卵巣腫瘍の20～25 \%程度を占める良性腫瘍で、日常遭遇する頻度の 比較的高い卵巣腫瘍の 1 つである。成熟囊胞性奇 形腫自体は後腹膜腔、大網、仙骨周囲、精巣、縦 隔など、身体の正中、傍正中に存在する臟器や構 造に発症する事例もある事が知られているが、多 くは卵巣に発生し、卵巣以外に発生する成熟囊胞 性奇形腫は $0.4 \%$ 程度を占めるのみである ${ }^{1)}$ 。中 でも本症例のように、骨盤腹腔内、特にダグラス 窩に認められる卵巣外成熟囊胞性奇形腫は稀であ り、我々が調べたところでは 20 例程度の報告しか なされていない2)。

卵巣外成熟囊胞性奇形腫の発生機序としてa) 肧芽期に迷入した生殖細胞から発生したとする 説 ${ }^{3.8)}$ 、b）副卵巣から発生したとする説 ${ }^{4.9)} 、$ c) 卵 巣成熟囊胞性奇形腫が自然脱落後異所性に生着し たとする説2.5,6,10,11)、が提唱されている（Table1）。

本症例において、腫瘍は腹腔内に存在し、右卵 巣との癒着は軽度であった一方、左卵管と紐状に 結合織がつながっていた。摘出した腫瘍の病理学

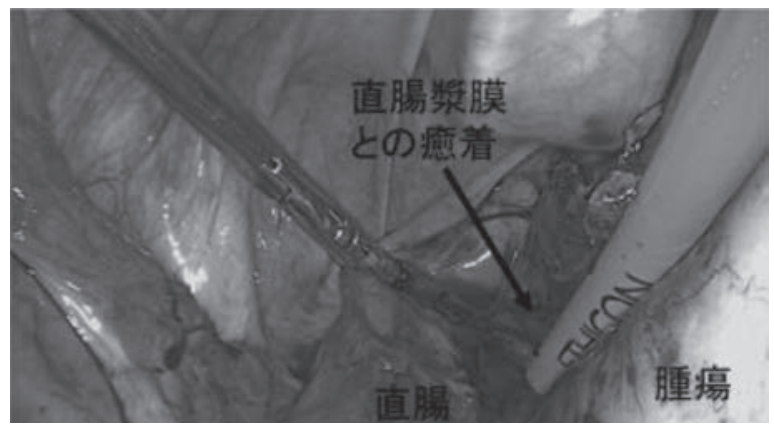

B

Figure 2: 術中所見

A: 腫瘍と子宮、右卵巣との癒着、左付属器との紐状構造物が 見られた。左卵巣は萎縮していた。

$\mathrm{B}:$ 直腸漿膜と腫瘍に癒着あり。慎重に剥離を行った。

C: 腫瘍と右仙骨子宮勒帯に、最も強い癒着が見られた。 


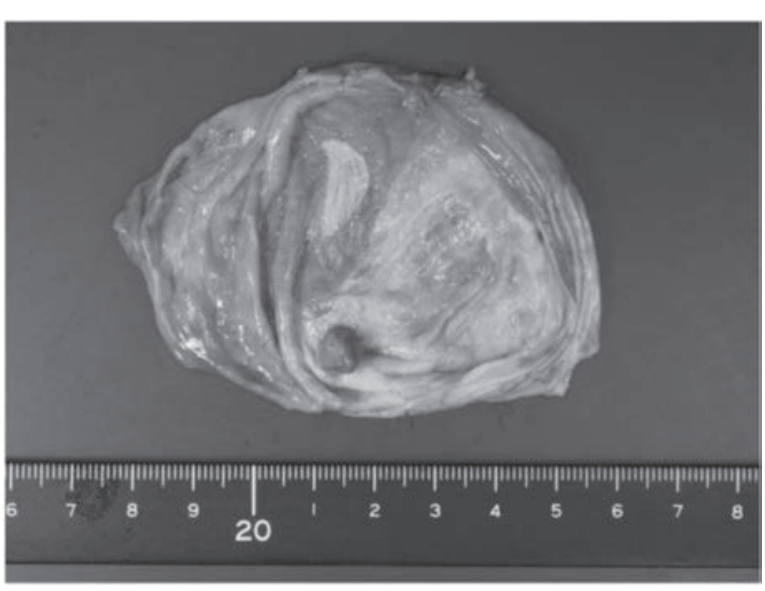

A

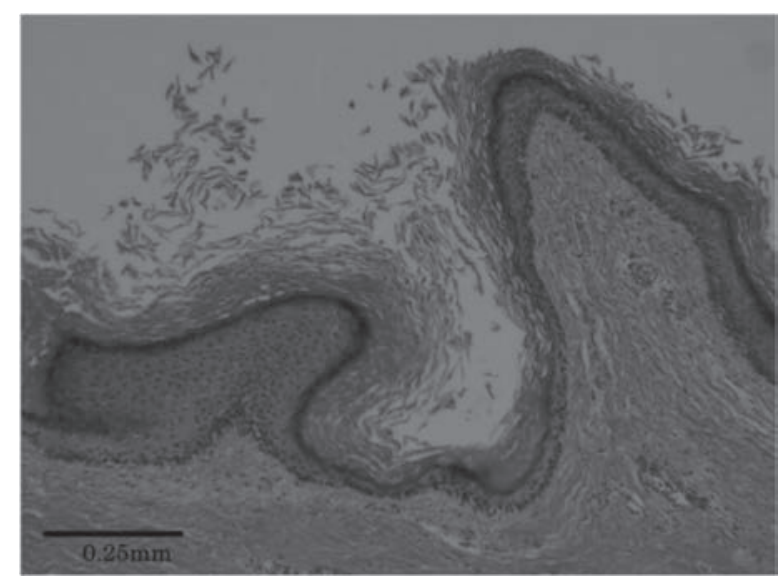

C

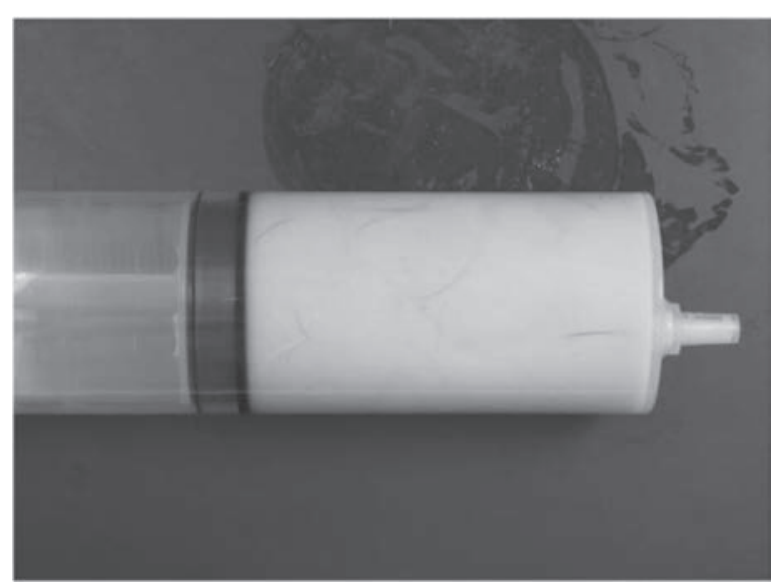

B

Figure 3 病理学的所見

A: 腫瘍切開面、肉眼的所見。単房性でRokitansky結節が見ら れた

B: 腫瘍内溶液。乳白色で脂肪成分、毛髪成分が含まれていた。

C: 病理組織学所見。40倍拡大視野。角化型重層扁平上皮を認 める。卵巣間質は見られず。

Table 1: ダグラス窩に認めた卵巣外成熟囊胞性奇形腫の報告

\begin{tabular}{|c|c|c|c|c|c|c|}
\hline & 年齢 & $\begin{array}{l}\text { 術 前 診 } \\
\text { 断 }\end{array}$ & 術中卵巣所見 & 病理学的所見 & 術式 & 推定発生機序 \\
\hline Takeda $5^{8)}$ & 49 & $\begin{array}{l}\text { 卵 巣 腫 } \\
\text { 瘍 }\end{array}$ & 異常無し & $\begin{array}{l}\text { 成熟囊胞性奇形腫 } \\
\text { 卵巣組織記載無し }\end{array}$ & 腹腔鏡下切除 & \multirow{2}{*}{$\begin{array}{l}\text { 胎芽期迷入細 } \\
\text { 胞・副卵巣から } \\
\text { の発生 }\end{array}$} \\
\hline Kobayashi 5 & 61 & $\begin{array}{l}\text { 卵巣 腫 } \\
\text { 瘍 }\end{array}$ & 異常無し & $\begin{array}{l}\text { 成熟囊胞性奇形腫 } \\
\text { 卵巣組織記載無し }\end{array}$ & 開腹術 & \\
\hline Kakuda M 5 & 41 & $\begin{array}{l}\text { 卵 巣 腫 } \\
\text { 瘍 }\end{array}$ & 萎縮 & $\begin{array}{l}\text { 成熟囊胞性奇形腫 } \\
\text { 卵巣間質あり }\end{array}$ & 腹腔鏡下切除 & \multirow[t]{5}{*}{$\begin{array}{l}\text { 自然脱落後 異 } \\
\text { 所性生着 }\end{array}$} \\
\hline Kusaka $5^{5)}$ & 24 & $\begin{array}{l}\text { 卵巣腫 } \\
\text { 瘍 }\end{array}$ & 左卵巣無し & $\begin{array}{l}\text { 成熟囊胞性奇形腫 } \\
\text { 卵巣間質あり }\end{array}$ & 腹腔鏡下切除 & \\
\hline Koo YJ $~^{10)}$ & 34 & $\begin{array}{l}\text { 卵巣 腫 } \\
\text { 瘍 }\end{array}$ & 変形 & 記載無し & 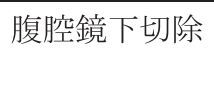 & \\
\hline Peitsidou 5 & 33 & $\begin{array}{l}\text { 診 断 無 } \\
\text { し }\end{array}$ & 右卵巣無し & $\begin{array}{l}\text { 成熟囊胞性奇形腫 } \\
\text { 白体女り }\end{array}$ & 開腹術 & \\
\hline 本症例 & 35 & $\begin{array}{l}\text { 腹 腔 内 } \\
\text { 腫瘍 }\end{array}$ & 左卵巣萎縮 & 卵巣間質無し & 腹腔鏡下切除 & \\
\hline
\end{tabular}


検査にて卵巣実質組織が見られなかったが、左卵 巣は右と比して萎縮している所見であった。その ため、迷入した生殖細胞から発生した、あるいは 副卵巣由来とは考えがたく、卵巣成熟囊胞性奇形 腫が自然脱落し、異所性に生着したものと考えら れる。

成熟囊胞性奇形腫の多くは、術前に主にMRIに よる画像検査の結果、診断される事が多い。多く の場合含有されている脂肪成分が、脂肪抑制 $\mathrm{T} 1$ 強調画像を用いることで明らかとなり、診断の一 助となる。今回も脂肪抑制 $T 1$ 強調画像で、脂肪 成分の存在が明らかとなり、成熟襄胞性奇形腫の 術前診断をつけることができた。成熟囊胞性奇形 腫は、良性が疑われていても、捻転や破裂のリス クが考えられる場合は手術適応となり、今日では 腹腔鏡下手術が選択される事が多い。

成熟囊胞性奇形腫の多くは卵巣原発であるが、 これまで述べたように、稀ながら卵巣外に発生す る事もある。大網に発生した成熟囊胞性奇形腫を、 当初卵巣原発と術前診断して手術加療を行った報

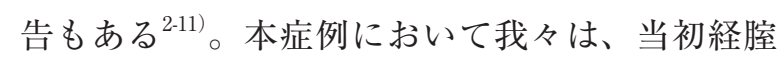
超音波にて正常左卵巣が描出された一方、右卵巣 が描出されず、腫瘍も右側に位置していた事から、 右卵巣原発腫瘍と考えた。しかしその後施行した MRI検查にて右卵巣も確認でき、稀な病態ではあ るが、骨盤腹腔内に存在する、卵巣外成熟囊胞性 奇形腫の可能性を術前に想定する事ができた。そ して、術中に判明した直腸漿膜との癒着について は、消化器外科医師との協力のもと、鏡視下に視 野を拡大して詳細に癒着部位を観察する事で、安 全に癒着剥離を施行する事ができた。

鏡視下に腫瘍の切除を行う場合、発生部位が卵 巣と異なる場合は特に、トロッカー位置や手術方 式の変更が必要となりうる。そのため、ともすれ ば卵巣原発であろうと詳細な検討が省かれる可能 性のある発生部位について、十分吟味する事が肝 要である。本症例では事前に卵巣外発生の可能性 を考えていたため、消化器外科との連携をスムー ズに行う事ができた。例えば大血管や尿管に近接 すると判断される場合は、心臟血管外科や泌尿器 科に事前に連携を求める事により、より安全な鏡 視下腫瘍切除術を行う事ができるであろう。

\section{結語}

術前に発生部位について詳細に検討を行い、そ の結果卵巣外成熟囊胞性奇形腫の可能性を考え て、鏡視下に腫瘍を摘出しえた 1 例を経験した。
卵巣外成熟囊胞性奇形腫は稀ではあるが、その可 能性を排除する事無く、手術に望む前に発生部位 を詳細に検討する事は非常に重要である。そして 卵巣外が発生母地と考えられる場合は、必要に応 じて他科との連携を行う事で、安全な鏡視下手術 が遂行できると考える。

本論文の要旨は第57回日本産婦人科内視鏡学会 において発表した。

本論文に関わる著者の利益相反 ; すべての著者 は開示すべき利益相反はない。

\section{文献}

1) Yoshida Atsushi, et al. : Case of mature cystic teratoma of the greater omentum misdiagnosed as ovarian cyst. J Obstet Gynaecol Res 2005 ; 31 : 399403.

2) Kakuda Mamoru, et al. : A case of extragonadal teratoma in the pouch of Douglas and literature review. J MINIM INVAS GYNL $2015 ; 22$ : 13111317.

3) Fujimoto Toyoaki, Yukihiko Miyayama, and Masatoshi Fuyuta. The origin, migration and fine morphology of human primordial germ cells. Anat Rec $1977 ; 188$ : 315-329.

4) Wharton Lawrence R. Two cases of supernumerary ovary and one of accessory ovary, with an analysis of previously reported cases. Am J Obstet Gynecol $1959 ; 78: 1101-1119$.

5 ) Kusaka Masumi, et al. : Ectopic ovary: A case of autoamputated ovary with mature cystic teratoma into the cul-de-sac. J Obstet Gynaecol Res 2007 ; 33 : $368-370$.

6) Ushakov Fedor B., et al. : Parasitic ovarian dermoid tumor of the omentum-A review of the literature and report of two new cases. Eur J Obstet Gynecol Reprod Biol $1998 ; 81: 77-82$.

7 ) 村上 幸祐, et al. : 腹胉鏡手術により摘出し得た大網 成熟囊胞性奇形腫の 1 例. 日本産科婦人科内視鏡学会 雑誌 $2016 ; 31: 439-443$.

8) Takeda Akihiro, et al. : Early abdominal pregnancy complicated by parasitic dermoid cyst: diagnosis by diffusion-weighted magnetic resonance imaging and management by laparoendoscopic single-site surgery. : J MINIM INVAS GYNL $2012 ; 19$ : 647650.

$9)$ Kobayashi Y., K. Kiguchi, and B. Ishizuka. : Mature cystic teratoma of the pouch of Douglas containing multiple mobile spherules. International Journal of Gynecology \& Obstetrics $2006 ; 92: 81-82$.

10) Koo Yu-Jin, et al. : Mature cystic teratoma of the 
uterosacral ligament successfully treated with laparoendoscopic single-site surgery. : Taiwanese Journal of Obstetrics and Gynecology 2012 ; 51 : 8688.

11) Peitsidou Aikaterini, et al. : Diagnosis of an autoamputated ovary with dermoid cyst during a Cesarean section. : Fertil Steril 2009 ; 91 : 1294-e9.

投稿日：2017年 9 月18日

採択日：2017年10月24日 